\title{
Justice Jean E.L. Côté, THe Court of APPeal, AND THE CHANGing NATURE OF CONTRACT LAW
}

\author{
DAVID PeRCY, Q.C. ${ }^{*}$ AND Douglas StOLleRY, Q.C.** \\ PANEL MODERATOR: SHANNON O'BYRNE***
}

I. Remarks: DAVId PerCY, Q.C.

\section{A. INTRODUCTION}

I would like to begin by acknowledging a series of debts which I owe to Jean Côté, two of which are personal and two are professional.

Those who know Justice Côté well freely acknowledge that he is an exceptionally kind friend and colleague. He exhibited these qualities to me at the beginning of my teaching career. In late August of my second year of teaching, it became clear that Dr. Alexander Smith would be unable to teach his section of the Contracts course because of ill-health. The law school also learned, to its surprise, that the incoming class numbered over 200 students (the class that graduated in June of that year consisted of about 70 students). I was nervous at the prospect of teaching a class of 140 students, but Justice Côté immediately volunteered to teach a double section. He very considerately thought it unfair to place such a task on a junior member of faculty, despite the fact that he was a sessional instructor with a very busy law practice.

He performed a similarly unexpected act of kindness just a year or so later. I had just published my first article on contracts, a somewhat unconventional account of the Doctrine of Frustration. I was suffering some trepidation about how the article would be received. Jean relieved a great deal of pressure when he called me at home one evening to say that he had very much enjoyed reading the article, even though he disagreed with its conclusions. It meant a great deal to me to learn that I had not completely bombed out with my first publication.

At a professional level, Jean made two important contributions to my life. In 1974, he published An Introduction to the Law of Contract, a book which was a lifeline to a young law professor. ${ }^{1}$ It was the first book on Contracts published in Canada since 1914 and provided a valuable roadmap to the development of the subject in this country. His second contribution came when I was a student in what was then the Bar Admission Course, in which Jean delivered his justifiably famous segment on Time Management. This made a huge difference

Professor, Border Ladner Gervais Chair of Energy Law and Policy, University of Alberta. His teaching and research interests lie in two fields: contracts and energy and natural resources law.

Chancellor, University of Alberta; President of the Stollery Charitable Foundation; Director of the Stephen Lewis Foundation and CARE Canada; Counsel, Reynolds Mirth Richards \& Farmer LLP. Professor, University of Alberta. She has published and delivered papers in the areas of good faith in contractual performance, recovery of mental distress damages in a breach of contract action, discrimination on the basis of sexual orientation, disclosure duties, economic justice, law and emotions, public law theory, as well as the relationship between law and literature. 
to my professional life. I can remember parts of the class almost verbatim, so I will briefly pass on Jean's wisdom for the benefit of the law students in the room.

A lawyer has to be available to his or her clients, but not 24 hours a day. There is no legal problem so large that it cannot be broken down into bite-size components. This should be your first task. You then need to identify your most productive time of the day and to isolate a two-hour period in which you will be free of interruptions. In this block of time, you should be able to crack one of the components of your case and prepare at least an outline of the problem. You should then spend the rest of the day attending to all the messages received from your clients during your period of sequestration. The next day, you should move on to the second component of the problem and continue on a segment-by-segment basis until you have covered its entire scope.

I can safely say that I follow this advice regularly in both dealing with practical legal problems and researching and writing projects. It explains why I am very grumpy if I am interrupted before 10:00 a.m.

\section{B. The Place of Contracts in Private LaW in 1987}

At the beginning of Justice Côté's judicial career, the law of contracts appeared remarkably tranquil on the surface. A commentator could look at the traditional categories of contract law and note that they had altered little over the years and conclude that, at most, the subject had undergone a few cosmetic changes. At a conference in 1975, celebrating the centenary of the Supreme Court of Canada, Dean Gerald Fridman was asked to address the role of the Supreme Court in the development of private law. He viewed this remit as "almost, though not quite, like giving a dog a virtually meatless bone on which to chew. The net result is to whet the appetite without providing any substance to satisfy what has been aroused. Or, if you prefer, salivation without salvation." ${ }^{2}$ He gave due credit to the significant contributions of the Supreme Court in the development of the law of unjust enrichment ${ }^{3}$ and recognized some innovations in the law of torts, but he was particularly critical of the law of contracts. He commented unfavourably on the inability of the Supreme Court to reevaluate the old doctrines of contract law and to provide insights into developments that had occurred in the English Courts. ${ }^{4}$ He called provocatively for the Supreme Court to set the tone for lower courts by addressing emerging private law problems boldly and imaginatively. ${ }^{5}$

During Justice Côté's tenure on the Court of Appeal, the technique of legal reasoning by the Supreme Court of Canada in most of private law underwent a startling change. The Supreme Court boldly staked new ground, most notably in the fields of unjust enrichment,

GHL Fridman, "The Supreme Court and the Law of Obligations” (1976) 14:1 Alta L Rev 149 at 149. Ibid at 154-55, focusing mainly upon Deglman v Guaranty Trust Co of Canada, [1954] 3 DLR 785 (SCC) and three cases decided in the 1960s: Eadie $v$ Township of Brantford, [1967] SCR 573; George (Porky) Jacobs Enterprises Ltd v City of Regina, [1964] SCR 326; County of Carleton v City of Ottawa, [1965] SCR 663.

4 Fridman, ibid at 149-50. Ibid at 159. 
fiduciary relations, and the law of torts. ${ }^{6}$ In these areas, the Supreme Court departed from the cautious approach criticized by Dean Fridman and set the law on new courses by issuing ambitious statements of general principle. For the purposes of these remarks, I will discuss two of the best known examples of the new style of reasoning.

As early as 1980, Justice Dickson provided the first example of a radically different approach. In Pettkus v. Becker, ${ }^{7}$ he formulated three elements that are required to establish an unjust enrichment: an enrichment, a corresponding deprivation, and the absence of any juristic reason for the enrichment. ${ }^{8}$ The three elements were problematic in the law of restitution, but they also marked a sea change in the Supreme Court's style of reasoning. Justice Dickson did not justify the three requirements by an analysis of existing law. Instead, they resulted from an innovative and personal synthesis of equitable and common law principles. In 2004, when the Supreme Court redefined the three elements in Garland v. Consumers' Gas Co., ${ }^{9}$ it did so in equally idiosyncratic terms. As Professor John McCamus stated, it "invented a novel analysis" of the third requirement of the Pettkus test by requiring the plaintiff to establish that there was no juristic reason for the transfer. ${ }^{10}$ This requirement for the plaintiff to prove a negative by ruling out any possible juristic reason for the transfers bore little resemblance to the existing common law. ${ }^{11}$ The Supreme Court's unanimous reframing of the requirements of unjust enrichment amounted to a declaration of broad principles that were not closely linked to precedent.

The Supreme Court embarked on an equally famous reformulation of fundamental principles in the area of fiduciary relationships. In Frame v. Smith, Justice Wilson distilled the ingredients of a fiduciary relationship into three requirements that focused on (1) the existence of discretion, (2) the unilateral exercise of power so as to affect the interests of the beneficiary, and (3) the vulnerability of the beneficiary. ${ }^{12}$ Although this statement of principle was described as a "rough and ready guide"13 and appeared in a dissenting judgment, it soon became the guiding framework for lower courts. ${ }^{14}$ Courts became preoccupied with refining the broad statements of principle over the next two decades. The unusual nature of these generalized statements of principle was noted throughout the Commonwealth. Famously, Sir Anthony Mason, the former Chief Justice of Australia, is said to have commented that in Canada "there are three types of persons: those who been held to be fiduciaries, those who are about to become fiduciaries; and judges."15

In extrajudicial writing, Chief Justice McLachlin has described this style of reasoning as an example of universalism, the quest for "broad, general principles underlying the

6

See for example the discussion of the Supreme Court's "refinement" of its approach to determining the duty of care summarized in Russell Brown, "Still Crazy After All These Years: Anns, Cooper v. Hobart and Pure Economic Loss" (2003) 36:2 UBC L Rev 159.

[1980] 2 SCR 834.

Ibid at 848 .

2004 SCC 25.

John D McCamus, "Forty Years of Restitution: A Retrospective" (2011) 50 CBLJ 474 at 490.

Ibid at 490-92.

[1987] 2 SCR 99 at 136 .

Ibid.

Peter D Maddaugh \& John D McCamus, The Law of Restitution, 2nd ed (Aurora, Ont: Canada Law Book, 2004) at 833 .

PA Keane, "The 2009 WA Lee Lecture in Equity: The Conscience of Equity" (2010) 10:1 Queensland U Technology L \& Justice J 106 at 107. 
imposition of responsibility and the corresponding rights of recovery." ${ }^{16}$ By its very nature, universalism is a top-down style of reasoning, which departed both from the common law and the traditionally inductive approach taken by the Supreme Court in its first century.

In contrast to other areas of private law, the Canadian law of contracts continued to develop more traditionally, in an incremental, bottom-up manner. For example, the Supreme Court began to modernize the doctrine of privity in a trilogy of cases decided over a sevenyear period in the 1990s. It did so through the familiar process of inductive analogy. In these cases, the Supreme Court significantly changed the legal positions of certain types of thirdparty beneficiaries in the traditional common law of privity. However, in contrast to other areas of private law, it expressly chose not to formulate any new principle to deal with third party issues. Instead it consistently emphasized that it was making only incremental changes in law that were only specific and limited exceptions to the doctrine of privity. ${ }^{17}$

\section{Justice Côté's Approach to Contracts}

Justice Côté's philosophy of contract law was at least consistent with the restrained approach followed by the Supreme Court of Canada during most of his career as an appellate justice. In 2012, he provided a typically trenchant summary of his views in the unanimous decision of Ko v. Hillview Homes Ltd. ${ }^{18}$ On its face, the case involved a set of facts that could easily have provided the basis for a first-year examination problem on uncertainty of terms. Briefly, the buyer alleged that it had entered a contract to purchase from a builder a standard new house (enticingly described as a Los Cabos II model) to be constructed in an area that was subject to strict architectural guidelines. The price of the house and lot was approximately $\$ 1.2$ million. Neither the Los Cabos model, nor any other house in the builder's catalogue, was large enough to satisfy the minimum size requirement of 4,500 square feet set out in the guidelines. The contract contained an entire agreement clause and one contentious term. Apparently, in order to ensure that the standard model 2,834 square foot house met the minimum 4,500 square foot requirement, the builder allowed the buyer to add 1,666 more square feet (or 59 percent) more than the standard design at a price of $\$ 80$ per square foot. The difficulty arose because none of the builder's standard homes were the necessary size and the contract offered no guidance as to where and how an additional 1,666 square feet could be grafted onto the original design. The purchaser had apparently agreed to buy a house plus a totally undefined addition. The property was neither defined by the contract nor ascertainable by any criterion established in the contract. The Court thus upheld the appeal and found that the contract was invalid.

16 Beverley McLachlin, "The Evolution of the Law of Private Obligation: The Influence of Justice La Forest" in Rebecca Johnson et al, eds, Gérard V. La Forest at the Supreme Court of Canada 19851997 (Winnipeg: Canadian Legal History Project, 2000) 21 at 22, quoted in Shannon O'Byrne \& Ronnie Cohen, "The Contractual Principle of Good Faith and the Duty of Honesty in Bhasin v. Hrynew" (2015) 53:1 Alta L Rev 1 at 15.

17 London Drugs Ltd v Kuehne \& Nagel International Ltd, [1992] 3 SCR 299 at 438 (an incremental change), 450 (a very specific and limited exception); Edgeworth Construction Ltd v ND Lea \& Associates Ltd, [1993] 3 SCR 206; Fraser River Pile \& Dredge Ltd v Can-Dive Services Ltd, [1999] 3 SCR 108

182012 ABCA 245 [Hillview Homes]. 
The decision of the Court was uncontroversial, but it enabled Justice Coté to establish two philosophical points about the interpretation of contracts and to support them for practical reasons.

The decision stated:

- " $[\mathrm{t}] \mathrm{he}$ overarching aim of contracts is to let two or more parties predictably govern themselves by their own self-imposed rules."19

- "usually certainty and predictability are more important than fairness in any particular contract." 20

These principles were grounded in practical concerns:

- "Canadian courts sometimes give the public and businesses certainty in contractual disputes. But too often they do not. Even a clearly-written signed formal contract leads often to years of discoveries, and days or weeks of trial. Each step explores the entire history of the contract's negotiation, the subjective musings of each party, and every possible after-the-fact disappointment or windfall." 21

- Sometimes courts go "astray by encouraging parol evidence, ignoring wholecontract clauses, inventing collateral unwritten obligations, and implying farreaching terms." They are reluctant to hold any agreement too uncertain to enforce and often do so "by inventing terms which the parties never imagined" or "leave the parties with a binding contract of unknown and understated content.",22

Justice Côté frequently illustrated his objective approach to contractual interpretation in construction cases that became very well-known in the industry. In Canadian National Railway Company v. Volker Stevin Contracting Ltd., the Court firmly rejected a trial decision which sought to add implied terms to C.N.'s strict standard form contract. ${ }^{23}$ It stated that the "contract expressly excludes implying any obligation on C.N.'s part which is not expressly imposed by the contract." 24 The Court commented that the reasons for the trial judgment "imply a number of terms which are nowhere in the express words of the contract documents, and indeed contradict the express words in varying degrees. ${ }^{\circ 5}$ It emphasized that, even in the absence of an entire agreement clause, it was improper to apply terms that contradicted the express terms of the contract.

My colleague Professor Shannon O'Byrne drew my attention to a case in which Justice Côté sat as a member of the Northwest Territories Court of Appeal to provide further background on his approach to contractual interpretation.

Ibid at para 2 .

Ibid at para 4 .

Ibid at para 6.

Ibid at para 8 .

1991 ABCA 287 [CNR].

Ibid at para 17. See also Graham Construction and Engineering (1985) Ltd v Alberta, 1992 ABCA 180. CNR, ibid. 
A strict construction of consumer standard form contracts is often fatal to an action brought by a disappointed consumer. However, in Bell Mobility Inc. v. Anderson, Justice Côté was able to construe such a contract against the service provider. ${ }^{26}$ Basically, Bell Mobility charged its subscribers in the Northwest Territories a fee of $\$ .75$ per month for 911 service. This seemed a little unfair, as there was no 911 service available in any of the three territories, with the exception of the city of Whitehorse. Justice Côte pointed out that the various cell phone contracts never actually stated that the consumer was obliged to pay for 911 service, as the relevant terms were "all conditional and ambiguous." ${ }^{27}$ Where, as in this case, "the wording of the contract is ambiguous, a court should be slow to adopt an interpretation which gives one party pay for nothing, or for what is virtually nothing." ${ }^{28}$ Bell tried to justify its right to payment by pointing out that if clients were to dial 911, they would be connected to a recorded message suggesting that they should call local emergency services, although the message did not provide any contact telephone number. Justice Côté dismissed this argument with a phrase that my colleague Professor Annalise Acorn has described as a "signature Jean-ism." He stated, "But to seek to charge for that by calling it 911 service, seems to me very unreasonable. It is like delivering to a starving person a photograph of a turkey dinner, and then charging him or her for a turkey dinner (or delivery of one). ${ }^{29}$

Justice Côté was able to deal with the Bell Mobility contract through the application of ordinary principles of interpretation. However, if a properly worded contract granted the right to charge for a non-existent or very limited 911 service, Canadian courts would face a challenge in avoiding its terms. The problems of standard form contracts have taken a different shape in recent years. It is now quite common for major corporations, especially multinational corporations, to seek to avoid potential liability through a compulsory dispute resolution clause that is very unfavourable to the consumer.

Since the decision in Tercon Contractors Ltd. v. British Columbia (Transportation and Highways), it is clear that the courts can only address the content of a standard form of contract through the doctrine of unconscionability. ${ }^{30}$ Justice Côté has been careful to emphasize that unconscionability is not just an unbridled and unruly horse, but a doctrine that is subject to strict requirements in Canadian law. He went to some lengths to emphasize its limits in Cain v. Clarica Life Insurance Company, in which he set out its four necessary elements:

1. a grossly unfair and improvident transaction; and

2. the victim's lack of independent legal advice or other suitable advice; and 
3. an overwhelming imbalance in bargaining power caused by victim's ignorance of business, illiteracy, ignorance of the language of the bargain, blindness, deafness, illness, senility, or similar disability; and

4. the other party knowingly taking advantage of this vulnerability. ${ }^{31}$

The application of unconscionability to a standard form contract is illustrated in the now well-known Supreme Court decision of Douez v. Facebook, Inc. ${ }^{32}$ In that case, the contract provided that all users of Facebook agreed to a forum selection and choice of law clause that required disputes to be resolved in California according to California law. There are many variations of these clauses in modern consumer contracts. They are basically designed to deter consumers from pursuing claims by, for example, requiring arbitration in a distant country and imposing an obligation on the losing party to pay all of the expenses of the winning party, including legal costs.

In the Douez case, the plaintiff claimed that Facebook had used her name and likeness without permission. Three members of the Supreme Court found that the plaintiff had established a strong case not to enforce the forum selection clause. The Supreme Court noted a number of cumulative factors. The contract was one of adhesion between a consumer and a large corporation, and it involved a statutory right that implicated a quasi-constitutional privacy right of British Columbia citizens. The contract involved a gross inequality of bargaining power between the parties and required a California tribunal to interpret the scope of privacy rights under British Columbia legislation. ${ }^{33}$

These findings were buttressed by two secondary factors. A British Columbia court is more able than a California court to assess the purpose and intention of a provincial statute and the expense and inconvenience of requiring British Columbian individuals to litigate in California outweighed the comparative expense and inconvenience to Facebook of litigating in British Columbia. ${ }^{34}$

The Douez case raises the question of the role of fairness in the interpretation of consumer standard form contracts. The prevailing "strong cause" principle states that a court should enforce a valid forum selection clause unless the plaintiff can show sufficiently strong reasons to support the conclusion that it would not be reasonable or just in the circumstances. ${ }^{35}$ The majority decision raises the question of whether the "strong cause" test involves the ordinary principles of unconscionability. Justice Abella, in a concurring judgment, agreed that Facebook could not take advantage of the forum selection clause if the plaintiff could establish that the contract was unconscionable. ${ }^{36}$ However, the judgment

2005 ABCA 437 at para 32, citing the statement of principles from Norberg $v$ Wynrib, [1992] 2 SCR 226 at $247-49$.

2017 SCC 33 [Douez]. I am grateful to Professor Shannon O’Byrne for her enlightenment on the unconscionability issue in this case.

Ibid at paras 51-63.

Ibid at paras 64-72.

ZI Pompey Industrie v ECU-Line NV, 2003 SCC 27 at para 39.

Douez, supra note 32 at para 112. 
suggested that unconscionability required only two elements: inequality of bargaining power and unfairness. ${ }^{37}$

In contrast, the three dissenting judges emphasized that inequality of bargaining power alone does not fulfil the requirements of the doctrine. In a nod to the Clarica decision, they stated that there must also be some relation of dependence or likelihood of undue influence and a bad bargain that contains an element of substantive unfairness. ${ }^{38}$

Unconscionability has assumed a greater role in Canadian contract law in recent years, but the Douez decision suggests that the requirements of unconscionability are clearly not yet settled. Some courts have confirmed the four-step test from the Clarica decision, ${ }^{39}$ while others consider that the test is excessively strict. ${ }^{40}$ Justice Côté's philosophy of contract law would suggest that it is dangerous to let loose a wide doctrine of unconscionability based on general conceptions of fairness without principles that impose some limits on its possible application.

\section{CONTRACTS In THE SUPREME COURT SINCE 2014}

Since late 2014, and almost coinciding with Justice Côté's retirement, there are distinct signs that the Supreme Court of Canada has extended the approach of stating "broad general principles underlying the imposition of responsibility"41 to the law of contracts. Ironically, the catalyst for this new approach was the unanimous decision of the Alberta Court of Appeal in Bhasin v. Hrynew, a case that involved the termination of a dealership agreement in the financial services industry. ${ }^{42}$

At the time of the Court of Appeal decision, the conventional view was that good faith was required in certain recognized relationships, such as franchises, employment, and fiduciary relationships, and in certain established categories of contract doctrine. The dealership agreement in Bhasin did not fall into any of these relationships, but it bore some similarities to both a franchise agreement and to an employment contract. Unless the case involved one of the established relationships, good faith was a requirement only in cases that fell into three broad categories, described by Professor McCamus: (1) where the parties must cooperate in order to achieve the objects of the contract; (2) where one party exercises a discretionary power under the contract; and (3) where one party seeks to evade contractual duties. ${ }^{43}$ The Bhasin case was not covered by any of these categories.

The Court of Appeal decision was broadly consistent with these requirements. It found that there is no general duty to perform contracts in good faith and that the dealership agreement was not an employment contract. ${ }^{44}$ The trial judge's decision to imply a term of

Ibid at para 115 .

Ibid at para 145 .

Phoenix Interactive Design Inc v Alterinvest II Fund LP, 2018 ONCA 98 at paras 38-40.

Downer $v$ Pitcher, 2017 NLCA 13 at paras 9-10.

McLachlin, supra note 16 at 22.

2013 ABCA 98 [Bhasin CA].

John D McCamus, The Law of Contracts, 2nd ed (Toronto: Irwin Law, 2012) at 840-56, cited in Bhasin $\checkmark$ Hrynew, 2014 SCC 71 at para 47 [Bhasin SCC].

Bhasin CA, supra note 42 at para 27. 
good faith performance did not satisfy the normal tests for the implication of a term and, even if it did, it was barred by an entire contract clause. ${ }^{45}$

The Supreme Court, in contrast, found that the existing categories of liability were examples of an underlying organising principle of good faith, which requires that parties "generally must perform their contractual duties honestly and reasonably and not capriciously or arbitrarily." ${ }^{\prime 46}$ Although the principle most commonly applies in the three categories of cases described by Professor McCamus, it can extend beyond them "where the existing law is found to be wanting and where the development may occur incrementally in a way that is consistent with the structure of the common law of contract and gives due weight to the importance of private ordering and certainty in commercial affairs." ${ }^{47}$ The Supreme Court overcame the entire contract rule by emphasising that the duty of good faith and honest performance does not arise from the parties' intentions or from an implied term of the contract but is imposed by the court as a minimum standard of conduct. ${ }^{48}$

It is safe to say that more words have been written about Bhasin v. Hrynew than any other case in the Canadian law of contracts. ${ }^{49}$ For the purposes of these remarks, it is important to underline that it states a new overriding principle that does not arise from the intention of the parties. Without this new approach, it would have been difficult to override the decision of the Court of Appeal, although the Supreme Court could possibly have done so by a more conventional inductive approach. The Supreme Court might, for example, have pointed out that the dealership agreement was somewhat similar to the existing categories of liability that apply to franchises and employment contracts. However, instead it deliberately chose to state a new universal principle.

\section{E. CONCLUSION}

I am certain that the courts' extension of universalism to the law of contracts is contrary to Justice Côté's philosophy and concern for practicality. If his career had not been cut short by retirement, he would have provided a counterweight to trends such as the emergence of a loose test for unconscionability and the development of a broad principle of good faith performance. He would also have been concerned by the fact that even if the recognition of the duty of good faith performance did not alter the results of many cases at the appellate level, it certainly imposes an increasing burden on trial judges. A survey conducted 11 months following the original decision showed that Bhasin had already been considered in 85 reported decisions across Canada. ${ }^{50}$ However, as any contract litigator will attest, the breach of the duty of good faith performance is alleged daily in contract cases, sometimes by both sides. As many of these arguments will ultimately have to be dealt with by judges,

Ibid at para 29.

Bhasin SCC, supra note 43 at para 63.

Ibid at para 66.

Ibid at para 74 .

This includes my own article, from which some of the ideas in these remarks are drawn. See David R Percy, "The Emergence of Good Faith as a Principle of Contract Performance," in Simone Degeling, James Edelman \& James Goudkamp, eds, Contract in Commercial Law (Pyrmont: Thomson Reuters Australia, 2016) 231.

$50 \quad$ Bradley Berg \& Mike Maoduw, "Bhasin Anniversary: You Gotta Have Faith?” (21 October 2015), online: Blake, Cassels \& Graydon LLP < https://www.blakes.com/English/Resources/Bulletins/Pages/ Details.aspx?BulletinID $=2206>$. 
it is my impression that the principle would also offend Justice Côté's concern for the sensible use of judicial resources.

\section{REPLY: DOUGLAS STOLlery, Q.C.}

It is a real honour to be invited to participate in this symposium with distinguished academics from the Faculty of Law. To the point raised by Professor Acorn, when I use the term "academics," I do so in the most positive sense.

In the brief time available to me, I would like to address three points. First, I will provide a few additional comments to the excellent analysis by Professor Percy of the contributions of Justice Côté to the law of contract. Second, I will speak briefly about the growing isolation of construction law from the judiciary. Finally, I will speak briefly about what I have learned personally and professionally from Justice Côté.

\section{A. The LaW OF Contract}

To the first point, in response to Professor Percy, I would like to start with a brief discussion of Justice Côte's views of the respective roles of the parties and the judiciary in establishing the terms of a contract. Succinctly stated, the parties make the deal and the judge enforces the deal that the parties have made, not the deal that the judge believes the parties should have made.

In Benfield Corporate Risk Canada Limited v. Beaufort International Insurance Inc. ${ }^{51}$ a decision issued in 2013, Justice Côté wrote:

\footnotetext{
Nothing is more dangerous than courts constructing contracts which the parties did not make, to make the contracts more businesslike or more just... Or to make them into what the court supposes would be more businesslike or more just.... Adequacy of consideration, or the fairness of the bargain, especially after the event, has never been a principle of contract law; the court's function is not to try to inquire into or supply that.
}

He went on to say:

Counsel and writers sometimes beguilingly suggest that the court's duty is to discover the intent of the parties. Does that mean bypassing the words of a formal signed contract in favour of the parties' competing assertions years later, all encased and cooked in a pastry shell of the trial judge's inferences and deductions? If so, it is wrong. The court is to interpret the words of the signed contract. ${ }^{52}$

Phrased in another way, and applying a "signature Jean-ism," in interpreting a contract, a judge should not turn himself or herself into a pretzel.

Justice Côté's view about the limited role of the judiciary in interpreting contracts is wholly consistent with his view that certainty and predictability are generally more important 
than the fairness of result in any particular case. I think it is important to put these views in context.

The law of contract involves the enforcement of commitments made by one person to another (person, in this context, of course including legal entities). The existence of the law of contract has enabled us to move from a society where all persons must source their own food, make their own clothing, and build their own shelter, to a society where persons may specialize in a particular task and rely on others to supply the other goods and services that they need or want. The law of contract is the foundation of our economy and a fundamental basis on which we have evolved as a society.

Every time we purchase a bag of groceries, fill up the tank in our car with gasoline, download an app to our phone, or agree to the use of cookies on websites we access, we enter into a contract. Every time we take on a new job, purchase an investment, or buy a home, we enter into a contract. Over the course of our lifetimes, each of us will enter into tens of thousands of contracts, some of great significance, others less.

Underlying each of those contracts is the assurance that we will get what we bargained for or that we will be compensated for the failure to get what we bargained for. It is in this context that certainty in the system as a whole is more important than fairness of the result of the enforcement of a particular contract, viewed after the fact by a judicial decision-maker.

Professor Percy spoke about the transition in the law of contract in Canada from tranquility at the beginning of Justice Côté's legal career to startling change at the end of his legal career. This brings to mind a passage from the book The Death of Contract written by Grant Gilmore in the early 1970 s. ${ }^{53}$ I remember this because I once used this passage in an examination I set for my class in Jurisprudence some years ago. Professor Gilmore wrote:

\footnotetext{
We have become used to the idea that, in literature and the arts, there are alternating rhythms of classicism and romanticism. During classical periods, which are, typically, of brief duration, everything is neat, tidy and logical; theorists and critics reign supreme; formal rules of structure and composition are stated to the general acclaim. During classical periods, which are, among other things, extremely dull, it seems that nothing interesting is ever going to happen again. But the classical aesthetic, once it has been formulated, regularly breaks down in a protracted romantic agony. The romantics spurn the exquisitely stated rules of the preceding period; they experiment, they improvise; they deny the existence of any rules; they churn around in an ecstasy of self-expression. At the height of a romantic period, everything is confused, sprawling, formless and chaotic - as well as, frequently, extremely interesting. Then, the romantic energy having spent itself, there is a new classical reformulation - and so the rhythms continue.
}

Perhaps we should admit to the possibility of such alternating rhythms in the process of the law. ${ }^{54}$

I think that Justice Côté may best be described as a classicist. In seeking to ensure certainty and predictability in the law of contract, he prefers logic and the application of rules over experimentation and improvisation. It may be that the pendulum of the law of contract 
is now swinging from classicism to romanticism. If Professor Gilmore is correct, in the fullness of time it will swing back.

\section{B. CONSTRUCTION LAW}

Moving on to my second topic, we have also been asked in this session to address the development of construction law, an area of particular interest to Justice Côté and to me. For the reasons I will discuss, this presents more of a challenge.

Construction is an inherently risky process. Contractors frequently commit to completing a particular project at a fixed price and by a fixed date. However, ground conditions may not be as expected, weather conditions may be extreme, materials - sometimes supplied from abroad - may not meet specifications, design may be inadequate or late or in error, labour productivity may be less than expected, subcontractors may default. Construction contracts have grown in length to address the allocation of these risks among the parties. In some contracts for public-private partnerships, the definitions section alone runs to over 200 pages. On a large, complex construction project, disputes about some element or elements of the work may be almost inevitable. Parties to construction contracts cannot practically resort to the courts for the resolution of all of those disputes. That is particularly true of disputes that occur during the course of the work where judicial proceedings to resolve those disputes may disrupt the progress or continuation of the work.

For all of these reasons, contracts for large, complex construction projects almost always include a dispute resolution provision, requiring various stages of discussions and negotiations between the parties and leading to arbitration. And for that reason, construction disputes rarely end up in court, including the Court of Appeal of Alberta.

These dispute resolution provisions may in general provide a more expedient mechanism for resolving construction law disputes. However, decisions typically are confidential. Confidentiality may be advantageous to the parties but regrettably does not assist in the development of the law. I am pleased that in his post-judicial career, Jean is undertaking the role of arbitrator in certain construction cases, so that his wisdom will be available to the industry in the resolution of disputes.

\section{WhAT I HAVE LEARNED FROM JUSTICE CôtÉ}

Moving on to my final topic, Jean Côté and I first met in May 1972. I had just finished my first year of Arts at the University of Alberta and had a summer job at the firm of Hurlburt Reynolds Stevenson and Agrios. Jean was a junior partner at the firm. I had shoulder-length hair. Jean had a brushcut. Ever since that day, I have looked to Jean as a mentor, a colleague, and a friend.

After I graduated from law school, I joined the firm and Jean and I practised law together for over a decade before his appointment to the Court of Appeal.

I remember one evening early in my career. I was working late on a project that I thought would never end. Jean came by my office, told me that I had ceased to be productive, and 
suggested that I go home. When I arrived at the office the next morning, the file was on my desk and the project was finished. Jean had come in early and completed the work for me.

I remember another evening early in my career when Jean again came by my office. It looked like the office of many other lawyers I have known, with files everywhere and papers piled high on my desk. Jean admonished me that I could not (or at least should not) work on more than one file at a time and that the rest of the files on my desk, and indeed all of the paper in my office, were just distractions from the task at hand. When I came in the next morning, my desk was bare except for a single file. Jean had diarized the rest of the files for appropriate dates and sent them off to the file room. I discovered that working at a clean desk was indeed more productive.

From these and countless other opportunities to work with Jean, I learned the importance of kindness to others and respect for my colleagues within my firm, within the profession, and on the bench. I learned the importance of organization and focusing on one task at a time. I learned the importance of research and logic and clear writing. And I learned how one dedicated person can truly make a difference to our profession and to the development of the law.

Thank you, Jean, for all of these lessons. 
[this page is intentionally blank] 